\title{
AN ETHICAL AND AN INTELLIGENT BUREAUCRATIC LAW REFORM
}

\author{
Jawade Hafidz \\ Sultan Agung Islamic University \\ hafidzjawade@gmail.com
}

\begin{abstract}
Bureaucracy and the law are two forces that must go hand in hand. Bureaucratic disregard the law when it goes limp bureaucratic system with no force because the bureaucratic system will not run when the law was abandoned. Bureaucracy in indonesia often look weak in a system. First rampant corruption in the bureaucracy is the main cause of dishonesty (actor) bureaucrats in understanding the nature of law. Breaking effects and misusing the mandate. Second, in our country as chaotic bureaucracy therein lies stagnation and the legal system in force when the bureaucracy that must be realized in accordance with the function and social role as a servant of the state. The third in the current law is enforced through a reformulation bureaucracy or bureaucratic reforms therein lies the role of bureaucracy is no longer comply with the law. Presence of bureaucracy in addition to be honest and transparent with the legal ethics bureaucracy is needed. Ethics is important in the bureaucracy. First, the existing problems in the bureaucracy becoming increasingly complex. Second, the success of development that has improved the dynamics and pace of change in the bureaucratic environment. Bureaucracy perform adjustment which requires discretionary power great.
\end{abstract}

Keywords: Bureaucracy Reform; Etics; Law;

\section{A. INTRODUCTION}

The beginning of reformation, there has been done a lot of mapping and analysis to save the "law" as one of the main pillars of this country. However, in practice, until now it has not shown a comprehensive and holistic improvement. This is happened since in encouraging legal reform, the involved parties are more likely to use a tactical approach to reform. Reformation is only one by fixing or patching defects, without making a thorough investigation and formulation, and forms a major update design, the improvements are often adhoc or patchy. ${ }^{1}$

The movement of democracy which demands legal reform to the realm of the bureaucracy is one of the important reviews from the perspective of bureaucratic law. When the law functions as a rule that is considered wise in determining the growth of democracy at the level of good government, that is where the law has full power as a rule and laws as a system of mobility for the integrity of democracy at the bureaucratic level.

1 Jawade Hafidz, Nawacita And the Law Enforcement Of Civil State Apparatus In Constitutional Law Perspectives In Indonesia, Jurnal Pembaharuan Hukum, Volume IV No. 2 May-August 2017, page.201-213 
Therefore reforms in the bureaucracy related to law are part of realizing national ideals of not involving the state as administrators of a legal system through an agreement. Quoting what William G. Andrew said that there are three elements of agreement in the constitution, namely, first about common goals and values in national life (the general goals of society or general acceptance of the same philosophy of government); second, regarding the basic rules as the basis for implementing the state and government (the basis of government); and thirdly regarding the institutions and procedures of state administration (the form of institutions and procedure). ${ }^{2}$

That the constitution on the one hand is the most important value that determines the limitation of power as a function of constitutionalism, although on the other hand it is an instrument for transferring authority from the original power holder, both the people in the democratic system and the figure of the king in the monarchy system to an organ of the state and government. Whereas the existence of a constitution is a basic element that has a vital role in the sustainability of state and government administration. $^{3}$

The presence of a constitution that manages the patterns and systems in the bureaucracy into an order that puts forward a formulation of the form of a state based on law such as in government administration also involves civil servants who are part of the state apparatus whose task is to provide services to the community in a professional, honest, fair and equitable In carrying out state duties, the government is in accordance with Article 3 paragraph (1) of Act No. 43 of 1999 concerning the Principles of Civil Service.

The bureaucracy, which is often said to be a servant of the state, when deviating from the nature of the law, will turn into a servant of the king or ruler in order to prosper the ruler, not the people. Democratic stuntness arises which can then weaken state law in its implementation.

On the one hand, when the law in the bureaucracy will be disciplined or enforced but sometimes it has implications in the form of the power of the ruler, for example, bureaucratic law that should run normally on the path of the provisions of the Law will crash and experience turbulent clashes in other spheres, such as politics to maintain its power and etc.

Apart from the laws that are carried out in the bureaucracy, it is also necessary to determine whether the law in the bureaucracy as above becomes an obstacle to the legal ethics of government and state bureaucracy when the power dominates its legal aspects. The worst impact is the development of the potential for collusion, nepotism, and corruption within the government and state bureaucracy. As the organizer of welfare, then the welfare of the rulers will become manifest because bureaucratic

2 Moh Mahfud MD, Penataan Hukum Dalam Rangka Menuju Good Governance. Mahfud said in a seminar at Udayana University Bali on September 29, 2010, page.2.

3 Jimly Assiddiqie, Hukum Tatata Negara dan Pilar-pilar Demokrasi; Serpihan Pemikiran Hukum, Media dan HAM, Konstitusi Pers, Jakarta, 2005, page.24. 
ethics and law are no longer the forces of honesty, work and service to the wider community.

According to Ismail Muhammad, bureaucratic reform is reform on a large scale (national) starting in 1998. The focus of reform is in three areas, namely the economic sector, the political sector and the legal sector. ${ }^{4}$ Meanwhile, in particular, bureaucratic reform began in 2004, and as pilot projects were the Supreme Audit Agency, the Supreme Court, and the Ministry of Finance. In 2008, the PAN Ministry published General Guidelines for Bureaucratic Reform. Starting in 2010, the Grand Design for Bureaucratic Reform 2010-2025 was established based on the Presidential Regulation of the Republic of Indonesia No. 81 of 2010, and followed up by the Minister of PAN Regulation No. 4 of 2010.

So we can all stare together if someone says that bureaucratic reform is running in that place because it does not follow current developments. Then from the policy side of implementing bureaucratic reform there have been concrete steps. Talking about bureaucratic reform in any country is not as fast as turning a hand, but it requires a long process. For example, Australia, reforming will take 30 years and the results can be seen.

The purpose of this study is to identify and analyze reforms. Bureaucratic ethics in the government bureaucracy has an important role to play in overcoming problems in the government bureaucratic structure and can optimize bureaucratic performance.

\section{B. RESEARCH METHODS}

The method that researchers use is juridical Normative research is legal research regarding the enactment or implementation of normative legal provisions in action at any particular legal event that occurs in society. ${ }^{5}$ This research uses the concept of law where, law is positive norms in the national legal system of legislation, the research is doctrinal, namely law is a manifestation of the symbolic meanings of social behavior as seen in their interactions. Non-doctrinal legal research, the approach uses qualitative research. This research is based on the legal positivist concept which states that legal norms are identical to written norms and are made and promulgated by the competent state institutions. $^{6}$

\section{RESULT AND DISCUSSION}

\section{Fairness in Credit Agreements with Standard Clause}

In the epistemology of the formal rules of the Big Indonesian Dictionary (KBBI) of the Ministry of Education and Culture, ethics is described in three definitions as follows; (1) knowledge of what is good and what is bad and about moral rights and obligations (morals). (2) a

4. Ismail Muhamad, Birokrasi Dalam Era keterbukaan Informasi Publik, Jurnal Dialog Kebijakan Publik, Vol 3 September 2011, page. 10

5 Abdulkadir Muhammad, Hukum dan Penelitian Hukum, Citra Aditya Bakti, Jakarta, 2004, page.134.

6 Ronny Hanitiyo Soemitro, Metodologi Penelitian Hukum, Ghalia Indonesia Jakarta, 1990, page.132. 
collection of principles or values relating to morals. And (3) values regarding right and wrong held by a group or society.

While Bertens's view, ethics comes from ancient Greek. The singular form of the word 'ethics' is ethos, while the plural form is 'ta etha'. Ethos has many meanings, namely: the usual place of residence, pasture, stable, habits or customs, morals, character, feelings, attitudes, ways of thinking. Meanwhile, the meaning of ta etha is custom. So, etymologically, ethics means the knowledge of what is commonly done or the knowledge of customs. He said that the basic concept of ethics is the study of human behavior and moral principles and the morality of a person to do good and also to determine the truth or error and one's behavior towards others.

Important things in ethics need to be fostered and developed in the implementation of government bureaucracy, for example, administrative ethics functions according to the application in their field, which will make a person able to be disciplined, responsible for all attitudes and actions that are carried out. Ethics in the government bureaucracy has an important role to play in overcoming problems in the government bureaucratic structure and can optimize the performance of the bureaucracy in providing services to the community. According to Dwiyanto $^{8}$

There are several reasons why bureaucratic ethics is important to consider in the development of an efficient, responsive and accountable government:

a. The problems faced by the government bureaucracy in the future will be even more complex. The increasing modernity of society has given birth to various public problems which are increasingly numerous and complex and must be resolved by the government bureaucracy.

b. The success of development that has increased the dynamics and speed of change in the bureaucratic environment. The dynamics that occur in the environment, of course, require the ability of the bureaucracy to make adjustments in order to remain responsive to ongoing changes.

Specifically, the basic values and ethics of civil servants as the main elements of government organizations have been regulated in Government Regulation Number 42 of 2004 concerning Corps Soul Development and Civil Servant Code of Ethics. These basic values that must be upheld by every civil servant, are: (1) devotion to one and only God; (2) loyalty and obedience to Pancasila and the 1945 constitution; (3) spirit of nationalism; (4) prioritizing the interests of the state above personal or group interests; (5) obedience to laws and regulations; (6)

7 K. Bertens, Etika, PT Gramedia Pustaka Utama, Jakarta, 1997, page.23

8 Dwiyanto Agus, Partini, Ratminto, Wicaksono Bambang, Tamtiari Wini, Kusumasari Bevaola, and Nuh Muhamad, Reformasi Birokrasi Publik Di Indonesia, Pusat Studi Kependudukan dan Kebijakan (PSKK), Universitas Gajah Mada, Yogyakarta, 2000, page.34 
respect for human rights; (7) is not discriminatory; (8) professionalism, neutrality and high morals; and (9) corps spirit.

We also need to cultivate issues regarding the rules and ethics of civil servants which have been regulated in Government Regulation no. 42 of 2004, which consists of:

a. Ethics in the state, which includes: (a) fully implementing Pancasila and the 1945 constitution: (b) enhancing the dignity of the nation and state; (c) become the glue and unifier of the nation and the unitary state of the Republic of Indonesia; (d) comply with all applicable laws and regulations in carrying out tasks; (e) being accountable in carrying out clean and authoritative governance tasks; (f) responsive, open, honest and accurate and timely in implementing any government policies and programs; $(\mathrm{g})$ use or utilize all state resources efficiently and effectively; (h) fail to provide false testimony or false testimony.

b. Organizational ethics, namely: (a) carrying out duties and authorities in accordance with applicable regulations; (b) safeguarding confidential information; (c) implement any policies stipulated by the competent authority; (d) build a work ethic to improve organizational performance; (e) cooperate cooperatively with other related work units in order to achieve objectives; (f) have competence in carrying out their duties; (g) comply with and comply with operational standards and work procedures; (h) develop creative and innovative thinking in order to improve organizational performance; (i) oriented to efforts to improve the quality of work.

c. Ethics in society, namely: (a) realizing a simple lifestyle; (b) to provide service with empathy, respect and courtesy, selflessly and without coercion; (c) provide prompt, precise, open and fair services and are not discriminatory; (d) responsive to the condition of the community environment; (e) oriented towards improving the welfare of the community in carrying out tasks.

d. Ethics towards oneself, namely: (a) being honest and open and not providing false information; (b) act with sincerity and sincerity; (c) avoid conflicts of personal, group or class interests; (d) taking initiatives to improve the quality of knowledge, abilities, skills and attitudes; (e) have high fighting power; (f) maintain physical and spiritual health; (g) maintaining family integrity and harmony; (h) have a simple, neat and polite appearance.

e. Ethics towards fellow civil servants, namely: (a) mutual respect for fellow citizens of different religions or beliefs; (b) maintain a sense of unity and unity among civil servants; (c) mutual respect between peers both vertically and horizontally within a work unit, agency, or between agencies; (d) respect differences of opinion; (e) uphold the dignity of civil servants; (f) maintain and establish cooperative cooperation among civil servants; $(\mathrm{g})$ assembling in one organization the employee corps of the republic of Indonesia which guarantees 
the realization of solidarity and solidarity of all civil servants in fighting for their rights.

The basic reason for ethics in the form of law in the bureaucracy can be understood as the basis for how state administrators, both central and local governments, stick to the rules and do not deviate from the laws that have been drafted by the state.

The government has a pattern of behavior that must serve as a guideline or code of ethics for each of its officers. Ethics in the bureaucracy must be generated based on a basic understanding that reflects the system that lives in society and must be guided and realized by every apparatus in the life of the community, nation and state. In general, ethical values that need to be used as guidelines and need to be practiced operationally include: (1) Officials are obliged to serve the public interest. (2) The apparatus is the motor that drives the "head" and "heart" for the life of the community, nation and state. (3) The apparatus must stand in the middle, be open and impartial (mediator). (4) The apparatus must be honest, clean and authoritative. (5) The apparatus must be discretionary, able to distinguish between secret and nonconfidential, important and insignificant. And (6) the apparatus must always be wise and protectors.

That the government bureaucracy in the relationship between ethics and law is a mutually exclusive construction between systems and functions to achieve welfare goals. This is in line with Weber's thinking that places the bureaucracy hand in hand because the bureaucracy is an open institution (state administrator) and can be understood according to its function of the apparatus. Policies and an atmosphere of democratization are needed, namely to provide broader rights for people to participate in the government process in ensuring a correlation between the performance of the bureaucracy for the social community.

In addition, the bureaucracy as part of law enforcement needs to be reformed with the dimension of justice. What is needed is to complete the "national building", maximize the function of institutions, build comprehensive legal rules and build morality of law enforcement officials. $^{9}$

Therefore bureaucratic ethics is closely related to the morality and mentality of the bureaucratic apparatus in carrying out the functions of government itself which is reflected in the main functions of government, service functions, regulations or regulations and the community empowerment function. ${ }^{10}$

Bureaucracy is also intended to regularly organize a job that is done by many people, bureaucracy is a type of organization to achieve large administrative tasks by systematically coordinating the work of

9 Moeljarto Tjokrowinoto, Saiful Arif (Edt), Birokrasi dalam Polemi, Pustaka Pelajar, Yogyakarta, 2001, page.42

10 Frans Magnis Suseno, Etika Politik; Prinsip-prinsip Moral Dasar Kenegaraan Modern. Gramedia, Jakarta, 1987, page.65 
many people. Bureaucracy as a work system is intended as a work system based on a cooperative relationship between positions directly regarding formal issues according to applicable procedures and the absence of sentiment without emotion or favoritism, without strings attached and prejudice.

What we want to highlight here is a relationship between offices, officials, institutional units and government departments. In this relationship system, how a delivery of ideas, plans, orders, values, feelings and goals can be well received by other parties as recipients by way of delivery must be easy and precise and based on law. In carrying out their duties and authorities, bureaucrats must be based on a high level of perception and legal awareness, as for the characteristics of bureaucracy, namely: (1) full implementation of organizational principles; (2) there are rules that are strictly obeyed; (3) officials work with full attention according to their respective abilities (sense of belonging); (4) officials are bound by discipline; (5) officials are appointed based on technical conditions based on regulations (meryt system); (5) there is a clear separation between official and personal matters.

In carrying out the state bureaucracy, every official in carrying out his duties is equipped with two principles, namely: ${ }^{11}$ first, the principle of legality. This principle means that none of the actions or decisions of the officials or bureaucrats concerned may be carried out without the basis of a statutory provision, for this reason officials or bureaucrats must pay attention to the eight elements of legality, namely written regulations, dissemination or use of regulations. not retroactive, understandable regulations, not contradicting one another, not demanding beyond the ability of people, not changing frequently and according to regulations and their implementation. Second, Ermessen's Principle of Freies or Discretion. This means that officials or bureaucrats must not refuse to make decisions on the grounds that there are no regulations, therefore they are given the freedom to make decisions according to their own opinions as long as they do not violate the principle of legality.

In everything that the apparatus does, especially the state administration, it can be seen what are the rights, obligations, responsibilities and roles of the state administrative apparatus. The rights and obligations that must be carried out by a state administrative apparatus (bureaucrat) are: ${ }^{12}$

a. Obligatory or obedient to the prevailing laws and regulations;

b. Must make a policy regarding a matter even though there are no regulations governing it, this is in accordance with freies ermessen;

c. Must be in accordance with the arrangement of the division of tasks;

d. Obliged to implement organizational principles;

e. Obliged to implement the General Principles of Good Governance. 
When the bureaucracy no longer fulfills the obedience of laws or regulations as above, the bureaucracy that should work to serve and side with the people develops into serving the rulers with sides to politics and power. So far, society has the view that the bureaucracy (state administration) is the same as the government, even though the two are different and cannot be equated. The bureaucracy is a state tool that needs to have its own rules of the game and is supported by separate legislation, therefore the correlation between the bureaucracy and the executive must be regulated in such a way that the bureaucracy actually works as a servant of the state and not as a servant of power.

In fact, bureaucratic ethics in government is closely related to doing the right things for the people, not only for officials or their officials. In the development of modern society, bureaucratic ethics and public administration ethics are mutual learning and mutual influence. In government bureaucratic ethics, starting to talk about the public policy approach (public policy approach) in the relationship between government and society. Public administration ethics that are reinventing the government by applying moves in running the bureaucracy, inevitably, are increasingly vulnerable to problems that usually arise in bureaucratic ethics, changes in systems, structures and government bureaucratic culture which are the essence of the implementation of good governance. It is even more debated in seminar rooms or in the academic world, while the main actors, namely government officials, are more impressed that they are still running in place. Even in certain cases, the changes that will be carried out often encounter obstacles or resistance from parties who feel aggrieved, both internally and externally. Therefore, it is understandable if the bureaucratic reform carried out by the government, both at the central and regional levels, is more political than based on the needs and demands of the organization. ${ }^{13}$

Likewise, government officials in running government and providing services to the community must have ethics that are in accordance with the expectations of the community, so as to maintain public trust in the government. Ethics is useful to help people determine the moral response to a situation or direction of action that is not clear; guide the leader in deciding what to do in different situations; and assist the leadership in deciding how to respond to the demands of the various stakeholders of the organization.

The success of the government for the welfare of the people is determined by the government's managerial ability to make optimal use of all potentials. Government bureaucratic ethics are required to develop creative and innovative thinking to formulate policies, programs and services to the community, as well as to empower productive assets (HR) in order to improve community welfare.

13 Iwan Satibi, Ediyanto, Etika Dan Perilaku Birokrasi Dalam Mendukung Penguatan Good Governance, Jurnal Academia Praja, Volume 3 Nomor 2 August 2020, page.234-250 
In improving people's welfare, it must be harmonized with the economic side of the community. Talking about the ability of the people to control or oversee the course of the economy, means talking about in whose hands sovereignty is in the hands of the state or in the hands of the people. ${ }^{14}$ According to the constitution, sovereignty should be in the hands of the people. The government is required to formulate various creative policies in order to respond and anticipate the demands of the changing society, environmental developments that are constantly changing, and also prepare to enter globalization with fierce competition.

A good political system coupled with a conducive political atmosphere will facilitate law enforcement and vice versa if the system and political atmosphere is chaotic it will greatly hinder law enforcement. To realize good law enforcement, it also needs a good political order and practice. Especially the law must be able to respond to the dynamics of the development of people's thinking so that the law does not work in place. $^{15}$

That's where the law applies and becomes a tool to improve the system so that it becomes more optimal and intensive. When HR gives strength to the prospective value of the law, the level of bureaucratic performance is no longer an obstacle to the sustainability of the jurisdiction for a better.

\section{Bureaucratic Design}

To maximize the law so that it continues to run based on ethical and legal standards, two things are needed. First, is the principle of law. The government, private sector and professionals are the main elements of involvement in monitoring technological developments in Indonesia. Second, reviewing national laws and regulations that are directly or indirectly related to the emergence of the problems that arise. ${ }^{16}$

Why bureaucratic management tends to act differently in relatively different time and space settings. This becomes the basis for a fundamental question whether the changes made by the bureaucracy are in accordance with the reform function desired by the general public, or is it just a formality as a structural obligation that tends to status quo; or only as a machine tool to manipulate and mobilize the people to submit to bureaucratic power (machine bureaucracy)?

This opinion reminds us of a rigid bureaucratic theology due to normative law. But we also need to rethink whether the law in

14 Anis Mashdurohatun, Kurnia Halomoan, Gunarto, The Urgency Of The Public Policy Of The Construction Service Cooperatives In Realizing The Welfare Of The Community Based On Justice Value, Hamdard Islamicus, Vol. 43 No. 1 (2020), page.355-367.

15 Jawade Hafidz, Agung Widodo, Pelanggaran Perpres Nomor 54 Tahun 2010 Tentang Pengadaan Barang Dan Jasa Pemerintah Oleh Penyedia Barang Dan Jasa Atau Pengguna Jasa Dalam Perspektif Tindak Pidana Korupsi, Jurnal Pembaharuan Hukum, Volume II No. 2 May- August 2015, page.151-161.

16 Jawade Hafidz, Kajian Yuridis Dalam Antisipasi Kejahatan Cyber, Jurnal Pembaharuan Hukum, Volume I No.1 January-April 2014, page.32-40. 
bureaucratic matters can always fulfill ethical elements when we clash with the important role of ethics and norms in the bureaucratic structure. In the opinion of someone named Islamy; ${ }^{17}$ There are various factors that cause the public bureaucracy to experience organizational slack, namely, among others, a rigid service orientation or approach, a narrow service vision, inadequate control of administrative engineering, and increasingly fat public bureaucratic units that are not facilitated by $3 \mathrm{P}$ (personnel, adequate and reliable equipment and budgeting (viable bureaucratic infrastructure).

As a result, the public bureaucratic apparatus becomes sluggish and is often trapped into routine activities, is not responsive to public aspirations and interests and is weak in adapting to changes that occur in their environment in accordance with laws and bureaucratic laws and ethics. As a consequence, is it true that the position of the public service apparatus as a framework for a tool of power or the bureaucracy is the ruler itself when faced with a number of causes relating to society or its clients.

There is a kind of bureaucratic selfishness when it is not balanced and in line with the law and sees the important side of bureaucratic ethics and governance. The disappearance of the a priori attitude towards law and the leniency of the bureaucracy towards the interests of the authorities resulted in the corruption of ethical and moral values which resulted in the cult of nepotism, collusion, and corruption.

This reminds us of a number of names of bureaucratic elites who have been caught up in legal problems due to the loss of ethics and the fading of law obedience towards themselves to carry out their responsibilities. That is why the bureaucracy as long as it is not based on ethics, norms and obedience to the law will result in the death of the bureaucracy, its legal responsibility and application.

According to data from the Ministry of Law and Human Rights, the bureaucracy that has been planned in a large platform called bureaucratic reform has fulfilled various objectives from various aspects and prospects for the future. Therefore, to carry out the tasks referred to, the Ministry of Law and Human Rights carries out the following functions and an excerpt from the design:

a. formulation, stipulation and implementation of policies in the field of law and human rights;

b. management of state property/assets which are the responsibility of the Ministry of Law and Human Rights;

c. supervision of the implementation of duties within the Ministry of Law and Human Rights;

d. implementation of technical guidance and supervision of the implementation of affairs of the Ministry of Law and Human Rights in the regions;

17 Islamy, Muhammad Irfan, Agenda Kebijakan Reformasi Administrasi Negara, Malang, Faculty of Administrative Sciences -University of Brawijaya, Malang, 1998, page.7 
e. implementation of technical activities on a national scale; and

f. implementation of technical activities from the center to the regions

Therefore, the legal design that calls for a change in the bureaucratic system from a legal perspective is to look to the future to the long-term stages as follows;

\section{GRAND DESIGN OF REFORM BUREAUCRACY}

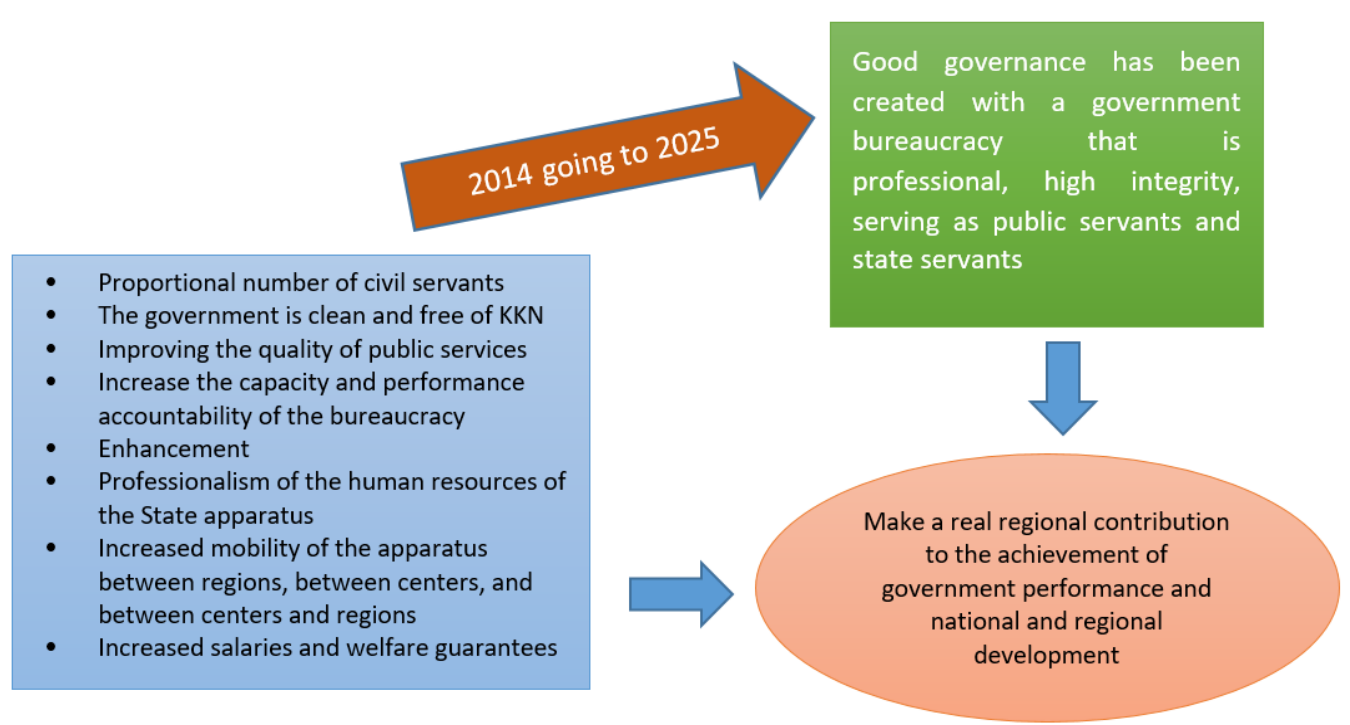

Bureaucratic governance is the order of a country. When the bureaucracy in the mainset is corrupt, the state is indicated to be corrupt, even though the bureaucracy has been designed and there has been bureaucratic reform and is not well organized, the state will have the impact of becoming a failed state in the context of governance, especially law.

Examining the law at the bureaucratic level emphasizes the disciplinary aspects of work procedures and prioritizes the absence of violations of duties and authorities in the bureaucratic body. Because the law in question is more positioned as a magnet in the form of constituents in the context of creating good government values. This is realized by enforcing the law at the level of the state bureaucracy.

In the context of democracy, law becomes a pillar for all citizens who must be obeyed. In a strategy that focuses on law enforcement, it is carried out by applicable legal regulations. ${ }^{18}$ No exception to ethics and norms in administering a form of achieving a clean, honest, and fair bureaucracy in creating human values legally. According to Herbert M. Levine, bureaucracy is sometimes used in a way that is belittled, it can

18 Bahtiyar Efendi, Anis Mashdurohatun, Sri Endah Wahyuningsih, Involving the Role of Army to Strengthen Police's Law Enforcement of Terrorism in Indonesia, International Journal of Pharmaceutical Research, April-June 2021, Vol 13 Issue 2, page.402-406 
be said that it means clumsy, unimaginative, clumsy, and inefficient government administrators. ${ }^{19}$

\section{CONCLUSION}

The bureaucracy plays an active role in the political process in most countries and the bureaucracy uses a lot of activities, among them the most important efforts are the implementation of laws, preparation of legislative proposals, economic regulation, licensing in the economy and professional matters, and sharing welfare services. The crucial thing that supports the creation of bureaucratic values that is balanced with the agenda of the welfare of the country is that law and ethical order and norms in the bureaucracy are not only a design and concept of bureaucratic change or reform but also a concept of legal reformulation that we should uphold together.

\section{Book:}

\section{BIBLIOGRAPHY}

Abdulkadir Muhammad, 2004, Hukum dan Penelitian Hukum, Citra Aditya Bakti, Jakarta;

Dwiyanto Agus, Partini, Ratminto, Wicaksono Bambang, Tamtiari Wini, Kusumasari Bevaola, dan Nuh Muhamad, 2000, Reformasi Birokrasi Publik Di Indonesia, Pusat Studi Kependudukan dan Kebijakan (PSKK), Universitas Gajah Mada, Yogyakarta;

Frans Magnis Suseno, 1987, Etika Politik; Prinsip-prinsip Moral Dasar Kenegaraan Modern, Gramedia, Jakarta;

Herbert Levine Charles, Peters.Guy.8, \& Thompson. Frank.J, 1990, Public Administration: challenges, Choices, Consequences, Glenview, A Division of Scott, Foresman and Company, Illinois London;

Islamy, Muhammad Irfan, 1998, Agenda Kebijakan Reformasi Administrasi Negara, Malang, Faculty of Administrative Sciences -University of Brawijaya, Malang;

Jimly Assiddiqie, 2005, Hukum Tatata Negara dan Pilar-pilar Demokrasi; Serpihan Pemikiran Hukum, Media dan HAM, Konstitusi Pers, Jakarta;

K. Bertens, 1997, Etika, PT Gramedia Pustaka Utama, Jakarta;

Moeljarto Tjokrowinoto, Saiful Arif (Edt), 2001, Birokrasi dalam Polemi, Pustaka Pelajar, Yogyakarta;

Moh Mahfud MD, 2010, Penataan Hukum Dalam Rangka Menuju Good Governance, sebuah seminar di Universitas Udayana Bali pada 29 September, Bali;

19 Herbert Levine Charles, Peters.Guy.8, \& Thompson. Frank.J, Public Administration: challenges, Choices, Consequences, Glenview, A Division of Scott, Foresman and Company, Illinois London, 1990, page. 240-241 
Ronny Hanitiyo Soemitro, 1990, Metodologi Penelitian Hukum, Ghalia Indonesia Jakarta;

\section{Journal:}

Anis Mashdurohatun, Kurnia Halomoan, Gunarto, The Urgency Of The Public Policy of The Construction Service Cooperatives In Realizing The Welfare Of The Community Based On Justice Value, Hamdard Islamicus, Vol. 43 No. 1 (2020);

Bahtiyar Efendi, Anis Mashdurohatun, Sri Endah Wahyuningsih, Involving the Role of Army to Strengthen Police's Law Enforcement of Terrorism in Indonesia, International Journal of Pharmaceutical Research, Vol 13 Issue 2 April-June 2021;

Ismail Muhamad, Birokrasi Dalam Era keterbukaan Informasi Publik, Jurnal Dialog Kebijakan Publik, Vol 3 September 2011;

Iwan Satibi, Ediyanto, Etika Dan Perilaku Birokrasi Dalam Mendukung Penguatan Good Governance, Jurnal Academia Praja, Volume 3 Nomor 2 August 2020;

Jawade Hafidz, Kajian Yuridis Dalam Antisipasi Kejahatan Cyber, Jurnal Pembaharuan Hukum, Volume I No.1 January-April 2014;

Jawade Hafidz, Agung Widodo, Pelanggaran Perpres Nomor 54 Tahun 2010 Tentang Pengadaan Barang Dan Jasa Pemerintah Oleh Penyedia Barang Dan Jasa Atau Pengguna Jasa Dalam Perspektif Tindak Pidana Korupsi, Jurnal Pembaharuan Hukum, Volume II No. 2 MayAugust 2015;

Jawade Hafidz, Nawacita And The Law Enforcement Of Civil State Apparatus In Constitutional Law Perspectives In Indonesia, Jurnal Pembaharuan Hukum, Volume IV No. 2 May-August 2017; 